\title{
TINGKAT KEPUASAN MASYARAKAT TERHADAP KINERJA KEPEMIMPINAN KEPALA DESA LALOW KECAMATAN LOLAK KABUPATEN BOLAANG MONGONDOW
}

\author{
Devie S. R. Siwij \\ Program Studi Ilmu Administrasi Negara \\ Universitas Negeri Manado \\ E-mail: dsiwij@gmail.com
}

\begin{abstract}
ABSRACT
The purpose of this research is 1). To find out whether Lalow Village Leadership Lolak District Bolaang Mongondow District shows the expectations of the community? 2). To know what priorities should the village head have in its leadership? To answer the purpose of this research, the researchers conducted research based on the method of Importance and Performance Analysis used to obtain information about the level of community satisfaction of a service by measuring the level of importance and level of implementation. The results of the research show that 1). The average performance assessment of village chief leadership is below the average expectation (Importance): $2.47<3.6 .2$ ). The performance of each leadership variable from the score of respondents assessment (conformity level) below $100 \%(68.7 \%<100 \%)$ which means it has not been satisfactory. From the results of research and data analysis can be concluded that publik expectations of the overall value of Importance Performance Analysis (IPA) indicates that the leadership in Lalow Village District Lolak Bolaang Mongondow District is less than community expectations. which is quite high against the leadership of the village head.
\end{abstract}

Keywords: Leadership, Interests and Performance

\section{PENDAHULUAN}

Mengacu pada UU Desa No 6 tahun 2014, desa tidak hanya pemreintah desa dan kepala desa. Tetapi lebih dari itu kepala desa menempati posisi paling penting dalam eksisntensi penyelenggaraan pemabngunan sebuah desa. Bahkan seorang kepala desa memperoleh mandat politik dari rakyat desa melalui mekanisme demokrasi yaitu sebuah pemilihan langsung (Pilkades). Karena itu semangat undang-undang ini adalah adalah menempatkan kepala desa bukan sebagai kepanjangan tangan pemerintah, melainkan sebagai pemimpin masyarakat. Semua orang berharap kepada kepala desa bukan sebagai mandor maupun komprador seperti di masa lalu, namun sebagai pemimpin lokal yang mengakar pada rakyat. Artinya kepala desa harus mengakar dekat dengan masyarakat, sekaligus melindungi, mengayomi dan melayani warga.

Di sisi lain, Pembangunan pedesaan merupakan bagian integral dari pembangunan nasional. Usaha peningkatan kualitas sumberdaya pedesaan dan masyarakat secara keseluruhan, yang dilakukan secara berkelanjutan berlandaskan pada potensi dan kemampuan pedesaan. Pada pelaksanaannya, pembangunan pedesaan seharusnya mengacu pada pencapaian tujuan pembangunan.

Apapun yang dikerjakan seorang kepala desa sebagai kepala pemerintahan desa harus dapat menjalankan tugas pokok memimpin dan mengkoordinasikan pemerintah desa. Dalam melaksanakan sebagian urusan rumah tangga desa, melakukan pembinaan dan pembangunan perekonomian masyarakat desa. Di sisi lain, kepemimpinan kepala desa merupakan salah satu aspek yang menonjol dan berpengaruh terhadap keberhasilan pembangunan desa, desa dalam hal ini adalah organisasi sangat dipengaruhi oleh pemimpin. "Kepemimpinan adalah cara seorang pemimpin mempengaruhi perilaku bawahan agar mau bekerja sama dan bekerja secara efektif dan efisien untuk mencapai tujuan organisasi'[1]. 
Makna suatu kepemimpinan dapat dikatakan sebagai cara dari seorang pemimpin untuk mengatrur, mendorong dan mengarahkan seluruh unsur-unsur. dalam kelompok atau organisasinya guna mencapai suatu tujuan organisasi yang dikehendaki sehingga menghasilkan pelayanan pada masyarakat dengan maksimal. Bila dapat meningkatkan mutu pelayanan menunjukan tercapainya hasil kerja seseorang atau aparatur desa dalam mencapai tujuan organisasi.

Sebagai suatu organisasi formal yang bertugas menyelenggrakan roda pemerintahan tingkat terandah dalam wilayah Negara Kesatuan Republik Indonesia, Desa Lalow Kecamatan Lolak Kabupaten Bolaang Mongondow berkewajiban untuk melayani masyarakat untuk memenuhi haknya sebagai warga negara yang ada di desa tersebut. Dalam eksistensinya sebagai penyelenggara pelayanan publik, desa yang berpenduduk 1278 orang dengan jumlah $307 \mathrm{KK}$ sangat terlihat peran penting kepala desa dalam mendukung tugas yang dimaksud.

Secara umum dapat dikatakan bahwa kepemimpinan kepala desa dalam melaksnakan tugasnya dapat dikatakan baik oleh masyarakat, namun di lain pihak ada pula keluhan-keluhan masyarakat yang mengemuka sehubungan adnya kelemahan pelaksanaan pelayanan publik di desa Lalow, semisal urusan pengusulan KTP, KK, surat keterangan domisili bahkan pelayan pajak termasuk kegiatan desa lainnya yang melibatkan masyarakat.

Dari uraian di atas, maka peneliti tertarik untuk melakukan penelitian tentang kepuasan masyarakat pada kepemimpinan kepala desa yang ada di Desa Lalow Kecamatan Lolak Kabupaten Bolaang Mongondow. Adapun judul penelitian dapatlah dirumuskan sebagai berikut: Kepuasan Masyarakat Terhadap Kepemimpinan Desa Lalow Kecamatan Lolak Kabupaten Bolaang Mongondow. Berdasarkan judul di atas maka peneliti merumuskan permaslahannyaa sebagai berikut: 1). Apakah Kepemimpinan Kepala Desa Desa Lalow Kecamatan Lolak Kabupaten Bolaang Mongondow menunjukan harapan masyarakat ? 2). Bagaimana prioritas yang harus dilakukan oleh kepala desa dalam kepemimpinannya?
Kepala desa adalah bentuk pemerintahan yang interaksinya langsung berhadapan dengan masyarakat. Kepemimpinan kepala desa merupakan unsur penting untuk dapat mensukseskan pelaksanaan pembangunan desa. Kepala desa mempunyai tugas penyelenggaraan desa yaitu a). Bidang pemerintahan, antara lain pengaturan kehidupan masyarakat berdasarkan kewenangan desa seperti, pembuatan peraturan deaa, pembentukan lembaga kemasyarakatan, pembentukan badan usaha milik daerah, dan kerja sama antar desa, b). Bidang pembangunan, di antaranya pemberdayaan masyarakat guna penyediaan sarana dan prasarana fasilitas umum desa seperti, jalan desa, jembatan desa, irigasi desa, pasar desa. c). Bidang kemasyarakatan, yang terdiri dari pemberdayaan masyarakat dengan pembinaan kehidupan sosial budaya masyarakat, seperti bidang kesehatan, pendidikan dan adat istiadat [6]. Di sisi lain dapat dikatakan bahwa kepemimpinan adalah kegiatan untuk memengaruhi perilaku orang lain atau seni memengaruhi setiap perilaku manusia baik perorangan maupun kelompok dalam hal ini kepemimpian kepala desa.[2]

Kepemimpinan merupakan salah satu hal penting dalam penyelenggaraan organisai termasuk di desa, sebab sebagian besar keberhasilan dan kegagalan suatu organisasi sangat ditentukan oleh kepemimpinan dalam organisasi tersebut. Turney berpendapat bahwa kepemimpinan merupakan suatu grup proses yang dilakukan oleh seseorang dalam mengelola dan menginspirasikan sejumlah pekerjaan untuk mencapai tujuan organisasi melalui aplikasi teknik-teknik manajemen.[8]

Peranan atau fungsi kepemimpinan dikategorikan dalam tiga bentuk, yaitu: yang bersifat pengambilan keputusan, interpersonal, dan informasional. Kemudian dijabarkan dalam sepuluh kriteria diantaranya yaitu: pengambilan keputusan, actuating atau penggerakkan atau arahan, motivator, pimpinan, perencanaan dan pengawasan [3]

Bila kita mengacu pada pengertian sosiologi, desa ilustrasikan suatu bentuk kesatuan masyarakat atau komunitas penduduk yang bertempat tinggal dalam suatu lingkungan tertentu yang memunyai ciri khas antara laian: antara mereka saling mengenal, bentuk 
kehidupan mereka relatif homogen dan kebanyakan bergantung kepada alam, ukuran komunitasnya tidak terlalu besar, penduduknya tidak padat, adat istiadat masih dipegang dengan kuat, mobilitas sosialnya rendah, dan mempunyai kesetiakawanan yang tinggi [4].

Jika kita kaitkan dan beranggapan bahwa desa adalah suatu organisme, tentu saja desa mempunyai "kepala" yang berfungsi mengatur segala sesuatu. Kepala itu dikenal dengan sebutan kepala desa. Isitilah Kepala ini pada umumnya memiliki konotasi dengan adanya kedudukan dalam suatu hirarki atau struktur organisasi yang di dalamnya dan menegaskan adanya fungsi, wewenang serta tanggung jawab.

\section{METODOLOGI PENELITIAN}

Untuk mengukur tingkat kepuasan seseorang atas Kepemimpinan yang ditunjukan Kepala Desa Lalow Kecamatan Lolak Kabupaten Bolaang Mongondow digunakan rancangan atau desain penelitian Importance Performance Analysis (IPA) [5]. Peneliti akan membandingkan antara harapan masyarakat Desa Lalow dengan kepemimpinan yang dilakukan oleh kepala desa tersebut. Apabila tingkat harapannya lebih tinggi daripada kepemimpinan yang dilakukan oleh Kepala desa berarti masyarakat tersebut belum mencapai kepuasan, begitu pula sebaliknya.

Yang menjadi populasi dalam penelitian ini adalah adalah seluruh masyarakat Desa Lalow Sedangkan sampel diambil secara random dengan ukuran sampel mengacu pada pendapat Slovin [7], sehingga jumlah sampelnya sebesar 305 responden dengan presisi 0,05 .

Adapun definisi oprasional tentang Kepemimpinan Kepala Desa dalam penelitian ini adalah: Segala aturan kehidupan masyarakat dan pembangunan dengan indikator sebagai berikut:

1. Meningkatkan kesejahteraan masyarakat,

2. Memelihara ketentraman dan ketertiban masyarakat

3. Melaksanakn kehidupan demokrasi,

4. Melaksanakan prinsip tata pemerintahan desa yang bersih dan bebas dari KKN,

5 Menjaln hubungan kerja dengan seluruh mitra kerja pemerintahan desa,

6. Menaati dan meneggakan seluruh peraturan perundang-undangan,
7. Menyelenggarakkan

administrasi pemerintahan desa yang baik

8. Melaksanakan mempertanggungjawabkan keuangan desa,

9. Mendamaikan perselisihan masyarakat di desa.[6]

Dalam analisis data ini terdapat dua buah variabel yang diwakili oleh huruf $\mathrm{X}$ dan $\mathrm{Y}$, dimana $X$ adalah Kinerja Kepemimpinan Kepala desa Lalow sementara $Y$ adalah tingkat kepentingan masyarakat terhadap layanan Kinerja Kepemimpinan Kepala Desa . Adapun rumusnya adalah:

$$
T K i=\frac{X i}{Y i} X 100 \%
$$

Dan kepuasan msyarakat dapat dapat diukur dengan rumus:

$$
\bar{X} \iota=\frac{\sum X i}{n} \operatorname{dan} \bar{Y}=\frac{\sum Y i}{n}
$$

Dalam melakukan analisis tersebut, terlebih dahulu dilakukan uji validitas data dengan tujuan sebagai petunjuk sejauh mana suatu alat pengukur (instrumen) mengukur apa yang ingin diukur dan melakukan uji reliabilitas hal ini dimaksudkan untuk mengetahui apakah hasil pengukuran tersebut dapat dipercaya untuk digunakan dalam pengumpulan data atau tidak.

\section{PEMBAHASAN}

Untuk menentukan kinerja dan harapan setiap item adalah dengan menentukan intervalnya terlebih dahulu. Rumus yang dipakai untuk menentukan interval ini adalah $\mathrm{I}=\frac{\text { Range }}{K}$

\section{Penilaian Tingkat Kinerja}

Penilaian kinerja kepemimpinan kepala desa Lalow berdasarkan apa yang telah diterima. kemudian dinilai oleh responden terhadap 9 indikator yang diteliti maka hasilnya adalah seperti yang diterangkan table 1 sebagai berikut:

TABEL 1 PENILAIAN TINGKAT KINERJA KEPALA DESA

\begin{tabular}{|l|l|l|l|}
\hline No & $\begin{array}{l}\text { Atribut/Indikator Kinerja } \\
\text { Kepal desa }\end{array}$ & $\begin{array}{l}\text { Rata- } \\
\text { rata }\end{array}$ & Kategori \\
\hline 1 & $\begin{array}{l}\text { Meningkatkan } \\
\text { kesejahteraan masyarakat, }\end{array}$ & 2.5 & Baik \\
\hline
\end{tabular}




\begin{tabular}{|c|c|c|c|}
\hline 2 & $\begin{array}{l}\text { Memelihara ketentraman } \\
\text { dan ketertiban masyarakat }\end{array}$ & 2,43 & $\begin{array}{l}\text { Tidak } \\
\text { baik }\end{array}$ \\
\hline 3 & $\begin{array}{l}\text { Melaksanakn kehidupan } \\
\text { demokrasi }\end{array}$ & 2,38 & $\begin{array}{l}\text { Sangat } \\
\text { Tidak } \\
\text { Baik }\end{array}$ \\
\hline 4 & $\begin{array}{l}\text { Melaksanakan prinsip tata } \\
\text { pemerintahan desa yang } \\
\text { bersih dan bebas dari } \\
\text { KKN, }\end{array}$ & 2,52 & Baik \\
\hline 5 & $\begin{array}{l}\text { Menjalin hubungan kerja } \\
\text { dengan seluruh mitra kerja } \\
\text { pemerintahan desa, }\end{array}$ & 2,49 & Baik \\
\hline 6 & $\begin{array}{l}\text { Mentaati dan meneggakan } \\
\text { seluruh peraturan } \\
\text { perundang-undangan, }\end{array}$ & 2,37 & $\begin{array}{l}\text { Sangat } \\
\text { Tidak } \\
\text { Baik }\end{array}$ \\
\hline 7 & $\begin{array}{l}\text { Menyelenggarakan } \\
\text { administrasi pemerintahan } \\
\text { desa yang baik }\end{array}$ & 2,5 & Baik \\
\hline 8 & $\begin{array}{lr}\text { Melaksanakan dan } \\
\text { mempertanggungjawabkan } \\
\text { pengelolaan keuangan } \\
\text { desa, }\end{array}$ & 2,54 & $\begin{array}{l}\text { Sangat } \\
\text { Baik }\end{array}$ \\
\hline 9 & $\begin{array}{l}\text { Mendamaikan perselisihan } \\
\text { masyarakat di desa, }\end{array}$ & 2,45 & $\begin{array}{l}\text { Tidak } \\
\text { baik }\end{array}$ \\
\hline \multicolumn{2}{|c|}{ Total } & $\begin{array}{l}2,47 \\
(226.9)\end{array}$ & $\begin{array}{l}\text { Tidak } \\
\text { Baik }\end{array}$ \\
\hline
\end{tabular}

Berdasarkan data pada table 1 , menjelaskan bahwa indikator Melaksanakan kehidupan demokrasi dan mentaati dan meneggakan seluruh peraturan perundang-undangan dianggap sangat tidak baik oleh responden hal ini dibuktikan dengan indikator rata-rata sebesar 2,37 dan 2,38. Secara keseluruhan Kinerja kepemimpinan kepala desa Lalow adalah Tidak baik.

\section{Penilaian Tingkat Kepentingan}

Masyarakat Desa sebagai warga masyarakat dari kepala desa Lalow saat ini, akan meraskan manfaat kepemimpinan kepala desa apabila memenuhi tingkat kebutuhan/kepetingan dari masyarakat. Berdasarkan hasil penelitian, maka hasil analsis tingkat kepentingan dalam penelitian ini dapatlah digambarkan dalam table 2 sebegai berikut:
TABEL 2

PENILAIAN TINGKAT KEPENTINGAN MASYARAKAT TERHADAP KEPALA DESA

\begin{tabular}{|c|c|c|c|}
\hline No & $\begin{array}{l}\text { Atribut/Indikator } \\
\text { Kepemimpian Kepala } \\
\text { Desa }\end{array}$ & $\begin{array}{l}\text { Rata- } \\
\text { rata }\end{array}$ & Kategori \\
\hline 1 & $\begin{array}{l}\text { Meningkatkan } \\
\text { kesejahteraan masyarakat, }\end{array}$ & 3,3 & $\begin{array}{l}\text { Sangat } \\
\text { Rendah }\end{array}$ \\
\hline 2 & $\begin{array}{l}\text { Memelihara ketentraman } \\
\text { dan ketertiban masyarakat }\end{array}$ & 3,39 & Rendah \\
\hline 3 & $\begin{array}{l}\text { Melaksanakn kehidupan } \\
\text { demokrasi, }\end{array}$ & 3,42 & Rendah \\
\hline 4 & $\begin{array}{l}\text { Melaksanakan prinsip tata } \\
\text { pemerintahan desa yang } \\
\text { bersih dan bebas dari } \\
\text { KKN, }\end{array}$ & 3,21 & $\begin{array}{l}\text { Sangat } \\
\text { Rendah }\end{array}$ \\
\hline 5 & $\begin{array}{l}\text { Menjalin hubungan kerja } \\
\text { dengan seluruh mitra kerja } \\
\text { pemerintahan desa, }\end{array}$ & 3,84 & $\begin{array}{l}\text { Sangat } \\
\text { Tinggi }\end{array}$ \\
\hline 6 & $\begin{array}{l}\text { Mentaati dan meneggakan } \\
\text { seluruh peraturan } \\
\text { perundang-undangan, }\end{array}$ & 3.96 & $\begin{array}{l}\text { Sangat } \\
\text { Tinggi }\end{array}$ \\
\hline 7 & $\begin{array}{l}\text { Menyelenggarakan } \\
\text { administrasi pemerintahan } \\
\text { desa yang baik }\end{array}$ & 3,9 & $\begin{array}{l}\text { Sangat } \\
\text { Tinggi }\end{array}$ \\
\hline 8 & $\begin{array}{l}\text { Melaksanakan dan } \\
\text { mempertanggungjawabkan } \\
\text { pengelolaan keuangan } \\
\text { desa, }\end{array}$ & 3,82 & $\begin{array}{l}\text { Sangat } \\
\text { Tinggi }\end{array}$ \\
\hline 9 & $\begin{array}{l}\text { Mendamaikan perselisihan } \\
\text { masyarakat di desa, }\end{array}$ & 3,55 & Rendah \\
\hline \multicolumn{2}{|c|}{ Total Rata-rata } & $\begin{array}{c}3,6 \\
(330,2)\end{array}$ & Tinggi \\
\hline
\end{tabular}

Dari data table 2 di atas, secara keseluruhan indikator Tingkat kepentingan masyarakat terhadap kepemimpian kepala desa Lalow adalah tinggi. Hal ini berarti kinerja kepemimpinan kepala desa adalah hal yang penting bagi masyarakat Desa Lalow. 


\section{Hasil Penilaian IPA Tiap Variabel Kepemimpinan Keala Desa Lalow}

Berdasarkan tabel 3 di bawah ini diketahui rata-rata kinerja per variabel kualitas pelayanan adalah 227 dan rata-rata harapan 330 dan masing- masing kinerja kualitas pelayanan dari hasil skors penilaian responden adalah 69.03.

TABEL 3

PENILAIAN TINGKAT KESESUAIAN TERHADAP ASPEK-ASPEK KEPEMIMPIAN KEPALA DESA LALOW

\begin{tabular}{|c|c|c|c|c|}
\hline No & Unit Pelyanan & $\begin{array}{l}\text { Penilai } \\
\text { an } \\
\text { Kinerj } \\
\text { a }(X)\end{array}$ & $\begin{array}{l}\text { Penilai } \\
\text { an } \\
\text { Kepent } \\
\text { ingan } \\
\text { (Y) }\end{array}$ & $\begin{array}{l}\text { Tingk } \\
\text { at } \\
\text { Keses } \\
\text { uaian }\end{array}$ \\
\hline 1 & $\begin{array}{l}\text { Meningkatkan } \\
\text { kesejahteraan } \\
\text { masyarakat, }\end{array}$ & 230 & 304 & 75.7 \\
\hline 2 & $\begin{array}{l}\text { Memelihara } \\
\text { ketentraman dan } \\
\text { ketertiban masyarakat }\end{array}$ & 224 & 312 & 71.8 \\
\hline 3 & $\begin{array}{l}\text { Melaksanakn } \\
\text { kehidupan demokrasi, }\end{array}$ & 219 & 315 & 69.5 \\
\hline 4 & $\begin{array}{l}\text { Melaksanakan prinsip } \\
\text { tata pemerintahan } \\
\text { desa yang bersih dan } \\
\text { bebas dari KKN, }\end{array}$ & 232 & 295 & 78.6 \\
\hline 5 & $\begin{array}{l}\text { Menjaln hubungan } \\
\text { kerja dengan seluruh } \\
\text { mitra kerja } \\
\text { pemerintahan desa, }\end{array}$ & 229 & 353 & 64.9 \\
\hline 6 & $\begin{array}{l}\text { Mentaati dan } \\
\text { meneggakan seluruh } \\
\text { peraturan perundang- } \\
\text { undangan, }\end{array}$ & 218 & 356 & 61.2 \\
\hline 7 & $\begin{array}{l}\text { Menyelenggarakkan } \\
\text { administrasi } \\
\text { pemerintahan desa } \\
\text { yang baik }\end{array}$ & 230 & 359 & 64.1 \\
\hline 8 & $\begin{array}{l}\text { Melaksanakan dan } \\
\text { mempertanggungjawa } \\
\text { bkan pengelolaan } \\
\text { keuangan desa, }\end{array}$ & 234 & 351 & 66.7 \\
\hline 9 & $\begin{array}{l}\text { Mendamaikan } \\
\text { perselisihan } \\
\text { masyarakat di desa, }\end{array}$ & 225 & 327 & 68.8 \\
\hline & Rata-rata & 227 & 330 & 69,03 \\
\hline
\end{tabular}

Dari hasil perhitungan pada tabel 1, 2 dan

3 di atas,dapat disimpulkan bahwa:
1. Rata-rata penilaian kinerja (performance) kepemimpinan kepala desa di bawah rata-rata penilaian harapan (Importance ): 2,47 <3,6.

2. Kinerja dari masing-masing variabel kepemimpinan dari hasil skor penilaian responden ( tingkat kesesuaian) di bawah $100 \%(68,7 \%<100 \%)$ yang berarti belum memuaskan .

Berdasarkan perhitungan di atas, secara keseluruhan Nilai Importance Performance Analysis (IPA) menujukan bahwa kepemimpinan di Desa Lalow Kecamatan Lolak Kabupaten Bolaang Mongondow kurang dari harapan masyarakat. Hal ini juga didukung oleh harapan masyarakat yang cukup tinggi terhadap kepemimpina kepala desa di desa Lalow.

Pada Gambar 1 di bawah ini, akan menyajikan penilaian tingkat kepuasan masyarakat berdasarkan perhitungan rata-rata dan penyajian dalam bentuk diagram kartesius.

\section{GAMBAR 1 DIAGRAM KARTISIUS}

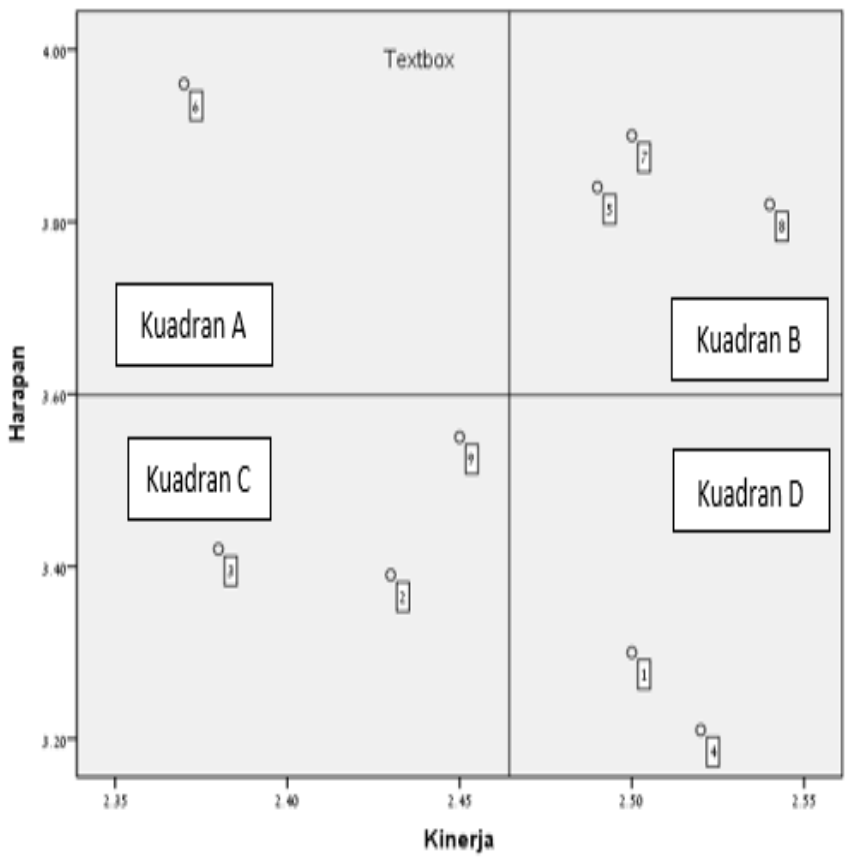

Indikator-indikator yang mempengaruhi kepemimpinan kepala desa

Adapun interpretasi dari diagram Kartesius tersebut dapat dijelaskan sebagai berikut :

1. Kuadran A (Prioritas Utama)

Menunjukkan aspek atau atribut yang mempengaruhi kepuasan masyarakat terhadap kepemimpinan kepal desa yang kinerjanya 
pelu diprioritaskan perlu diprioritaskan. Keberadaan aspek-aspek dalam kuadran ini dinilai sangat penting, tetapi kinerjanya masih tidak memuaskan yaitu pada aspek (No 6).

2. Kuadran B (Pertahankan Prestasi)

Menunjukkan aspek yang mempengaruhi kepuasan masyarakat Desa Lalow terhadap kinerja kepala desa perlu dipertahankan aspek yaitu (No 5), (No. 7) dan (No. 8)

3. Kuadran C (Prioritas Rendah)

Menunjukkan aspek kepemimipinan kepala desa yang mempengaruhi kepuasan masyarakat desa Lalow yang dianggap kurang penting pengaruhnya bagi masyarakat dan kinerjanya juga kurang bagus yaitu (No.2), (No.3) dan (No.9)

4. Kuadran D (Berlebihan)

Menunjukkan aspek-aspek yang mempengaruhi kepuasan masyarakat desa Lalow yang berada dalam kuadran ini dinilai berlebihan dalam pelaksanaannya. Aspekaspek tersebut adalah (No. 1), dan (no. 4)

Berkaitan dengan hasil penelitian ini, yang diharapkan masyarakat untuk dipenuhi dalam kepemimpina kepala desa adalah yang menurut mereka sangat penting untuk diprioritaskan dalam upaya perbaikan karena kinerja dari aspek tersebut jauh dari harapan. Aspek-aspek yang berada di atas sumbu Y (lebih besar dari 2.47). Oleh karena itu, aspek-aspek tersebut harus mendapat perhatian yang serius. Berdasarkan data hasil penelitian serta analisisnya dapat dikatakan bahwa dari kesembilan indikator yang diteliti dalam penelitian ini maka ada 4 aspek yang termasuk kategori baik yaitu (1),(4),(5) dan (7). Sedangkan yang terkategori sangat baik pelaksnaannya adalah aspek (8). Adapun aspekaspek yang dianggap sangat tidak baik dan tidak baik pelaksanaannya dalam kepemimpinan kepala desa adalah adalah (2),(3),(6) dan (9).

Kepala desa menjadi bagian penting dari suatu pemerintahan yang paling dekat dengan masyarakat. Kepemimpinan kepala desa sangatlah dibutuhkan untuk dapat mensukseskan pelaksanaan pembangunan desa [6]. Ada banyak tugas pemerintah desa Lalow yang dapat langsung berkontribusi kepada masyarakat sehingga terlaksnanya 9 indikator tersebut dengan maksimal dapat mendukung tugas pemerintah desa secara keseluruhan.
Dari hasil analysis ini menunjukan bahwa semua indikator yang diteliti dalam penelitian ini dinilai belum memenuhi harapan masyarakat, hal ini disebabkan kinerja kepemimpian kepala desa, nilainya masih di bawaha nilai harapan masyarakat. Secara keseluruhan kinerja kepemimpian kepala desa masih dalam kategori tidak baik dengan skor 2,47 (226.9) yang berbading terbalik dengan harapan masyarakat desa Lalow dengan skor total adalah 3,6 $(330,2)$ dalam kategori tinggi.

Peranan atau fungsi kepemimpinan dikategorikan dalam tiga bentuk, yaitu: yang bersifat pengambilan keputusan, interpersonal, informasional, kemudian dijabarkan dalam sepuluh kriteria diantaranya yaitu: pengambilan keputusan, actuating atau penggerakkan atau arahan, motivator, pimpinan, perencanaan dan pengawasan [3].

\section{KESIMPULAN DAN SARAN Kesimpulan}

1. Dari sembilan indikator penelitian yang dilakukan terhadap kemimpina kepala desa Lalow, empat Indikator menjukan kinerja baik dan 1 Indikator sangat baik.

2. Tingkat harapan masyarakat masih jauh lebih tinggi dari kinerja kepemimpinan yang ditunjukan oleh kepemimpian kepal desa Lalow.

3. Berdasarkan hasil Importance Performance Analysis (IPA) nilai kepemimpinan kepala desa mencapai $69,03 \%$ atau masih di bawah harapan masyarakat.

4. Indikator yang mempengaruhi kepuasan masyarakat desa Lalow terhadap kepemimpinan kepala desa yang perlu dipertahankan adalah: menjalani hubungan kerja dengan seluruh mitra kerja pemerintahan desa, (No. 5), meningkatkan kesejahteraan masyarakat,(No.7), memelihara ketentraman dan ketertiban masyarakat (No.8). 5).Secara keseluruhan Kinerja Kepemimpinan Kepala Desa Lalow belum memuaskan

\section{Saran}

1. Kepala desa dan jajarannya harus memahami kelemahan-kelemahan dari setiap indikator 
yang dinilai rendah untuk ditingkatkan kinerjanya.

2. Perlu membangun komunikasi yang serius antara kepala desa dan warga masyarakat agar terdapat sinkronisasi antara harapan masyarakat dengan kenerja kepemimpinan kepala desa yang dapat dilaksanakan secara maksimal.
3. Kepala desa harus meningkatkan kinerja kepemimpinannya yang sesuai dengan tuntutan masyarakat.

4. Kinerja Kepemimpinan Kepala Desa Lalow harus dilakukan perbaikan dan pembenahan agar dapat lebih baik dalam melaksanakan tugas melayani masyarakat.

\section{DAFTAR PUSTAKA}

[1] Hasibuan, Malayu S.P, 2003. Manajemen Sumber Daya Manusia, Edisi Revisi, Bumi Aksara, Jakarta.

[2] Miftah Thoha 2010. Kepemimpinan dan Manajemen, Devisi Buku Perguruan Tinggi, PT. Raja Grafindo Persada, Kakarta.

[3] Siagian, Sondang P. 2009. Kiat Meningkatkan Produktivitas Kerja. Jakarta. PT Rineka Cipta.

[4] Soelaeman, Moenandar. 2009. Ilmu Sosial Dasar : Teori dan Konsep Ilmu. Bandung : Refika Aditama.

[5] Supranto,J. 2006. Pengukuran Tingkat Kepuasan Pelanggan, Rineka Cipta, Jakarta

[6]

[7] Trisantono, Bambang Soemantri. 2011. Pedoman Penyelenggaraan Pemerintahan Desa.Bandung : Fokusmedia.

[8] Umi Narimawati. 2010. Penulisan Karya Ilmiah. Jakarta: Penerbit Genesis.

[9] Yamin, Martinis dan Maisah. 2010. Kepemimpinan dan Manajemen Masa Depan. Bogor: IPB Press 